\title{
Ozonation of estrogenic chemicals in biologically treated sewage
}

\author{
Hansen, Kamilla Marie Speht; Andersen, Henrik Rasmus; Ledin, Anna
}

Published in:

Water Science and Technology

Link to article, DOI:

10.2166/wst.2010.919

Publication date:

2010

Link back to DTU Orbit

Citation (APA):

Hansen, K. M. S., Andersen, H. R., \& Ledin, A. (2010). Ozonation of estrogenic chemicals in biologically treated sewage. Water Science and Technology, 62(3), 649-657. https://doi.org/10.2166/wst.2010.919

\section{General rights}

Copyright and moral rights for the publications made accessible in the public portal are retained by the authors and/or other copyright owners and it is a condition of accessing publications that users recognise and abide by the legal requirements associated with these rights.

- Users may download and print one copy of any publication from the public portal for the purpose of private study or research.

- You may not further distribute the material or use it for any profit-making activity or commercial gain

- You may freely distribute the URL identifying the publication in the public portal

If you believe that this document breaches copyright please contact us providing details, and we will remove access to the work immediately and investigate your claim. 
This was published in Water Science \& Technology 2010;62(3):649-57. doi: 10.2166/wst.2010.919. The publishers version is available at the permanent link: http://dx.doi.org/10.2166/wst.2010.919

\title{
Ozonation of estrogenic chemicals in biologically treated sewage
}

\author{
K. M. S. Hansen, H. R. Andersen and A. Ledin
}

Department of Environmental Engineering, Technical University of Denmark, Miljoevej B 113, DK-2800

Kongens Lyngby, Denmark (E-mail: kmh@env.dtu.dk; hra@env.dtu.dk; anl@env.dtu.dk)

\begin{abstract}
The present study shows that ozonation of effluents from municipal wastewater treatment plants (WWTPs) is likely to be a future treatment solution to remove estrogens and xeno-estrogens. The required ozone dose and electrical energy for producing the ozone were determined in two WWTP effluents for removal of 17 estrogenic chemicals. The estrogenic compounds included parabens, industrial phenols, sunscreen chemicals, and steroid estrogens. The obtained values of Electrical Energy per Order (EEOs) for the treatment of the estrogens were in the range $0.14-1.1 \mathrm{kWh} / \mathrm{m}^{3}$ corresponding to $1.7-14 \mathrm{~g} \mathrm{O}_{3} / \mathrm{m}^{3}$. It is furthermore suggested that UVabsorbance is a useful parameter for online control of the ozone dose in a full scale application since the absorbance of the WWTP effluents and the remaining concentration of the estrogens and xeno-estrogens correlated well with the applied ozone dose.
\end{abstract}

Keywords Estrogen; ozone; sewage; wastewater; xeno-estrogen

\section{INTRODUCTION}

The presence of estrogenic compounds in the environment, and particularly the continuous exposure via wastewater treatment plant (WWTP) effluents has in recent years received considerable attention due to their damaging effects on the aquatic life (Purdom et al., 1994; Routledge et al., 1998). The estrogenic compounds influence the endocrine system, resulting in behaviour change, change in mating behaviour and feminization of fish and frogs (Segner et al., 2003).

The synthetic steroid estrogen 17 1 -ethinylestradiol (EE2) is often found in low $\mathrm{ng} / \mathrm{L}$ concentrations in WWTP effluents, and available data suggest that it is an important contributor to the estrogenic activity of WWTP effluents (Desbrow et al., 1998; Routledge et al., 1998). The natural steroid estrogens, 17ß-estradiol (E2) and estrone (E1), are also considered important contributors to the estrogenic activity of WWTP effluents. They are less potent than EE2, but are typically found in slightly higher concentrations. Other known contributors to the estrogenic effect are industrial phenols such as nonylphenol (NP), octylphenol (OP) and bisphenol A (BPA) and compounds used in personal care products such as parabens and benzophenones. These are typically found in the $\mu \mathrm{g} / \mathrm{L}$ concentration range. However, these compounds have considerably lower estrogenic activity compared to steroidal estrogens (Brian et al., 2005).

Ozonation of effluents from WWTPs has recently emerged as a promising polishing technique to be applied on biologically treated municipal wastewater in order to remove bioactive xenobiotic micro pollutants like estrogens, xenoestrogens and pharmaceuticals (Huber et al., 2005; Joss et al., 2008; Ried et al., 2003, 2007; Ternes et al., 2003). The cost of the treatment depends on the required 
ozone dose, which varies with the quality of the effluent to be treated and the desired removal level for the pollutants. Over the years the reported dose of ozone required for satisfactory removal of steroid estrogens have decreased. The reported required dose was in the order of $5-10 \mathrm{mg} / \mathrm{L}$ in the first reports focusing on treatment of estrogens by ozone (Ternes et al., 2003). However, more recent studies have reported that doses in the range $2-3.5 \mathrm{mg} / \mathrm{L}$ would be sufficient (Huber et al., 2005; Bahr et al., 2007).

One of the challenges is to deliver the optimal dose of ozone, in order to keep the cost down, since the quality of effluents varies considerably both between WWTP plants and over time in the effluents of individual plants. In traditional applications of ozone in flow through reactors, used e.g. for drinking water pre-oxidation, the dose of ozone absorbed by the water can be determined by analysing the concentration of ozone in the gas effluent from the reaction chamber. This method cannot be used when a low dose of ozone is applied to WWTP effluents since the ozone in the gas is completely used if a properly designed reaction chamber is used. It was recently proposed by Bahr and coworkers (Bahr et al., 2007) to use the changes in the UV absorbance at $254 \mathrm{~nm}$, $\Delta \mathrm{Abs}_{254 \mathrm{~nm}}$, to characterise the dose of ozone used by the water. They showed an almost linear correlation between the dose of ozone in the relevant range and change in UV-absorbance for the WWTP effluent used in that study (Bahr et al., 2007). Bahr and coworkers also describe a good correlation between the removal of several pharmaceuticals and one steroid estrogen, estrone (E1), while the two other relevant steroid estrogens in WWTP effluents, 17 $\beta$-estradiol (E2) and 17 $\alpha$ ethynylestradiol (EE2), were removed at the lowest applied dose and therefore no relationship between dose and removal was established.

In this study the removal efficiency by ozonation of 17 estrogenic compounds was investigated in biologically treated sewage from two different WWTPs. The aims were to: i) determine the cost of any desired removal level of the compounds in terms of both ozone doze and electrical energy consumption and ii) to investigate the feasibity for online control of the ozone doze based on changes in UV-light absorbance during ozonation.

The compounds included in the investigation were parabens, industrial phenols, sunscreen chemicals, and steroid estrogens, which were spiked to batches of effluent water. The WWTPs chosen have somewhat different chemical composition of the effluents, determined by the treatment levels and the complexity of the source. Consequently the chemical oxygen demand (COD) and the absolute UV absorbance of the WWTP effluent at $254 \mathrm{~nm}$ were different. The efficiency of varying ozone doses on the removal of each compound was quantified, as well as the change in estrogenic effect, measured with a bioassay (YES-assay), and the UV-absorbance at $254 \mathrm{~nm}$.

Furthermore, by calculation from the ozone dose the electrical energy cost was estimated for the removal of each compound by ozonation both with the actual laboratory setup and recalculated to a full scale plant considering both oxygen and ozone production.

\section{MATERIALS AND METHODS}

\section{Reagents and materials}

All the estrogenic compounds investigated (Table 1) as well as all other chemicals used in the analytical procedures were analytical grade purchased from Sigma-Aldrich, Denmark.

The aqueous matrix used for the experiments were biologically treated effluents from Usserød WWTP and Lynetten WWTP. Both plants employ an activated sludge process with denitrification. Spiking of batches of effluents with the investigated chemicals were performed in concentrations 
10-100x the typical concentrations found in treated effluents, in order to ensure that data could be obtained for all chemicals considering analytical limits of quantification, but still have realistic kinetic. In practise this meant that the concentrations of xenoestrogens and the steroid estrogens were $1.0 \mu \mathrm{g} / \mathrm{L}$ and $40 \mathrm{ng} / \mathrm{L}$, respectively.

\section{Bench scale ozone reactor and experiments}

The treatment experiment was carried out in a customized bench scale, countercurrent set-up. The reaction chamber was $50 \mathrm{~cm}$ high with a volume of $2.0 \mathrm{~L}$. The water was pumped into the column at the top and was taken out from the bottom of the column. The ozone generator (OZ500, Dryden Aqua Ldt) was feed with dry oxygen, which resulted in a concentration of approximately $35 \mathrm{mg}$ $\mathrm{O}_{3} / \mathrm{L}$. The gas was let into the column in the bottom with a diffuser to create small bubbles in the water. Different levels of ozone dosage were obtained by varying the flow rate of the water. The wastewater effluent from Usserød WWTP and Lynetten WWTP were treated with 4 and 5 different ozone dosages, respectively, and ozone dosages between 1 and $9 \mathrm{mg} / \mathrm{L}$ was achieved.

\section{Ozone measurements, COD, UV-absorbance}

The ozone concentration in the gas was measured by UV-adsorption at $254 \mathrm{~nm}$ of the gas flowing in and out of the reaction chamber using a Varian Cary 50 photometer with a flow cell. The concentration of ozone in the outlet water was measured with an Allcon photometer (Alldos Gmbh, Germany) using the build in calibration curve which is based on the colour reaction with DPD (N,N-diethyl-p-phenylene-diamine).

COD was measured by the Danish standard method DS 217:1991 "Water examination. Determination of chemical oxygen demand in water $\mathrm{COD}_{\mathrm{cr}}$ with dichromate."

UV-absorbance was measured using a Varian Cary 50 photometer in $1.00 \mathrm{~cm}$ quartz cells. For each treatment dose of ozone a full spectrum of the water was recorded between 800 and $200 \mathrm{~nm}$.

\section{Sample preparation for chemical analysis and YES-assay}

Three samples of $1000 \mathrm{~mL}$ each was used for chemical analysis and one sample of $400 \mathrm{ml}$ for YESassay for each treatment experiment. Surrogate standard was added to all samples before solid phase extraction (SPE) to compensate for potential losses during sample preparation and analysis. The extractions were preformed with commercial packed cartridges (500 mg C18 adsorbent / $6 \mathrm{ml}$ cartridge, Supelco), which were conditioned with $2 \times 1.5 \mathrm{~mL}$ heptane, $1 \times 1.5 \mathrm{~mL}$ acetone, $2 \times 1.5$ $\mathrm{mL}$ methanol, and $2 \times 1.5 \mathrm{~mL}$ acidified water (phosphate buffer, $\mathrm{pH}=3$ ) before the extraction. The water was transferred to the SPE-column by the means of vacuum with a flow rate at maximum 5 $\mathrm{mL}$ per minute. Afterwards the column was dried for approximately 1 hour until completely dryness. The samples were eluted with acetone until $5 \mathrm{ml}$ eluent was collected in a test tube. Next, the eluent was dried under a stream of nitrogen in a thermostat controlled heating block to almost complete dryness.

The samples for YES-assay, to which no surrogate standard was added, were dissolved in ethanol while the samples for chemical analysis were further purified as described in the following. One gram of 1\% deactivated silica-gel (Silica gel 60, 0.063-0.200 mm (70-230 mesh ASTM) Merck) was suspended in $3 \mathrm{~mL}$ heptane-acetone mixture (65:35) and poured into $3 \mathrm{~mL}$ glass cartridge. The almost dried samples were redissolved in approximately $0.3 \mathrm{~mL}$ heptane acetone mixture (65:35) and transferred to the top of the silica-gel. The glass cartridge containing silica gel and sample was eluted with heptane acetone mixture (65:35) until approximately $5 \mathrm{~mL}$ eluent was collected. The solvent was evaporated under a stream of nitrogen to dryness. The samples were redissolved in 250 $\mu \mathrm{L}$ heptane-acetone mixture and transferred to a $\mathrm{GC}$ vial $(300 \mu \mathrm{L}, \mathrm{Chromacol})$. 


\section{Quantification of xenoestrogens}

The analysis of the estrogens was performed by gas chromatography using a Varian $3800 \mathrm{GC}$ coupled to Varian Saturn 2000 Iontrap (MS/MS). The column used was Zebron Inferno (ZB-5 HT, $30 \mathrm{~m} \times 0.25 \mathrm{~mm} \times 0.25 \mu \mathrm{m}$ ) with a gasflow of $1 \mathrm{~mL} / \mathrm{min}$. Seven and a half $\mu \mathrm{L}$ sample was injected using Varian 8200 Autosampler in split/splitless injection mode with the Varian 1079 PTV injection gate. The $\mathrm{GC}$ oven temperature was maintained at $100^{\circ} \mathrm{C}$ for $1 \mathrm{~min}$, then programmed at $20^{\circ} \mathrm{C} / \mathrm{min}$ to 110 , then $10^{\circ} \mathrm{C} / \mathrm{min}$ to 250 , followed by $25^{\circ} \mathrm{C} / \mathrm{min}$ to $285^{\circ} \mathrm{C}$, and finally $35^{\circ} \mathrm{C} / \mathrm{min}$ to $320^{\circ} \mathrm{C}$, which was hold for $7.1 \mathrm{~min}$. Each compound was quantified based on a characteristic daughter ion of MS/MS spectroscopy and the other daughter ions were used for confirmation of the identity of the detected chemicals.

\section{Quantification of steroid estrogens}

The samples for steroid estrogen analysis were transferred to $3 \mathrm{~mL}$ Reactivials ${ }^{\circledR}$. The samples were dried under nitrogen. The derivatisation mixture was made by mixing $2 \mathrm{mg}$ dithioerytrol (DTE), 2 $\mu \mathrm{L}$ trimethylsilylimidazole (TMSI), and $1000 \mu \mathrm{L}$ N-methyl-N-(trimethylsilyl)-tri-fluoroacetamide (MSTFA). To each sample $50 \mu \mathrm{L}$ of the mixture was added, which was capped and placed in an oven at $60{ }^{\circ} \mathrm{C}$ for $60 \mathrm{~min}$. Afterwards, the samples were evaporated to dryness under a stream of nitrogen and dissolved in $250 \mu \mathrm{L}$ heptane and transferred to GC-vials. The GC oven temperature was maintained at $80{ }^{\circ} \mathrm{C}$ for $1 \mathrm{~min}$, then programmed at $25^{\circ} \mathrm{C} / \mathrm{min}$ to $230^{\circ} \mathrm{C}$, followed by $1{ }^{\circ} \mathrm{C} / \mathrm{min}$ to $248{ }^{\circ} \mathrm{C}$, and finally $45{ }^{\circ} \mathrm{C} / \mathrm{min}$ to $320{ }^{\circ} \mathrm{C}$, which was hold for $3 \mathrm{~min}$. Each compound was quantified based on a characteristic daughter ion of MS/MS spectroscopy and the other daughter ions were used for confirmation of the identity of the detected chemicals.

The range of quantification was for xeno-estrogen in general between 0.005 and $1.0 \mu \mathrm{g} / \mathrm{L}$ and typically between 2 and $500 \mathrm{ng} / \mathrm{L}$ for the steroid estrogens.

\section{YES-assay}

The extracts were serially diluted in a growth media for yeast cells. The dilutions were incubated with an estrogen responsive yeast cell for $72 \mathrm{~h}$. The estrogenic effect was quantified by measuring the development of a red dye which is produced by the yeast cells with an enzyme and is produced proportionally to the estrogenic concentration in the cells. For quantification of the estrogenic effect a standard curve was made from a stock solution of $17 \beta$-estradiol (E2). The method for quantifying the estrogeic potency of the extracts is generally based on the method introduced by Routledge and Sumpter (1996).

\section{Data treatment}

The concentration of the ozone in the gas was calculated from the absorption using Beer-Lambert law. The molar absorption coefficient $(\varepsilon)$ used for ozone was $3000 \mathrm{NL} /(\mathrm{mol} \cdot \mathrm{cm}$ ) (regulation $002 / 87 \mathrm{~F}$ of the International Ozone Association, IOA). The ozone dose delivered to the wastewater was calculated as the amount of ozone in the inlet subtracted the amount in the water and gas outlets, which then was divided by the flow rate of the water.

\section{Determination of energy consumption}

The electrical energy dose (EED) is defined as the electrical energy (kWh) consumed per unit volume $\left(\mathrm{m}^{3}\right)$ of water treated (Bolton et al., 2001). The energy consumption of the laboratory ozone generator was measured with a wattmeter. The energy consumption was divided by the flow rate of the wastewater to find the energy dose at each treatment level.

\section{Electrical Energy per Order (EEO)}

The treatment effectiveness was evaluated based on the Electrical Energy per Order (EEO; unit $\mathrm{kWh} / \mathrm{m}^{3}$ ), which is defined as the electrical energy consumed per unit volume of water treated 
required for $90 \%$ removal of the investigated compound (Bolton et al., 2001). The normalised concentration of the investigated chemicals was plotted against the electrical energy dose. These plots were used for the estimation of the electrical energy per order. The curves were fitted to the data using nonlinear regression.

$$
\log \left(\frac{\mathrm{C}}{\mathrm{C}_{\mathrm{i}}}\right)=\frac{-1}{\mathrm{EEO}} \cdot \mathrm{EED}
$$

where $\mathrm{C}_{\mathrm{i}}$ and $\mathrm{C}$ is the initial and the final concentration, respectively, EED is the electrical energy dose in $\mathrm{kWh} / \mathrm{m}^{3}$ and EEO is the electrical energy per order. Constructed plots were used for determination of the EEO by least square fit according to Equation 1. In some cases concentration below the limit of quantification was used in the estimation of EEO if a good analytical signal was found with correct ratios between the daughter ions in the mass spectra.

\section{RESULTS AND DISCUSSION}

\section{Removal of chemicals and estrogenic potency}

The experiments showed that the investigated compounds could be removed by ozonation and that the degree of removal depended on the ozone dose applied. Generally all tested chemicals showed a close correlation between the applied ozone dose and the fraction removed as exemplified for four chemicals in Figure 1. Results for all chemicals are presented in Table 1.
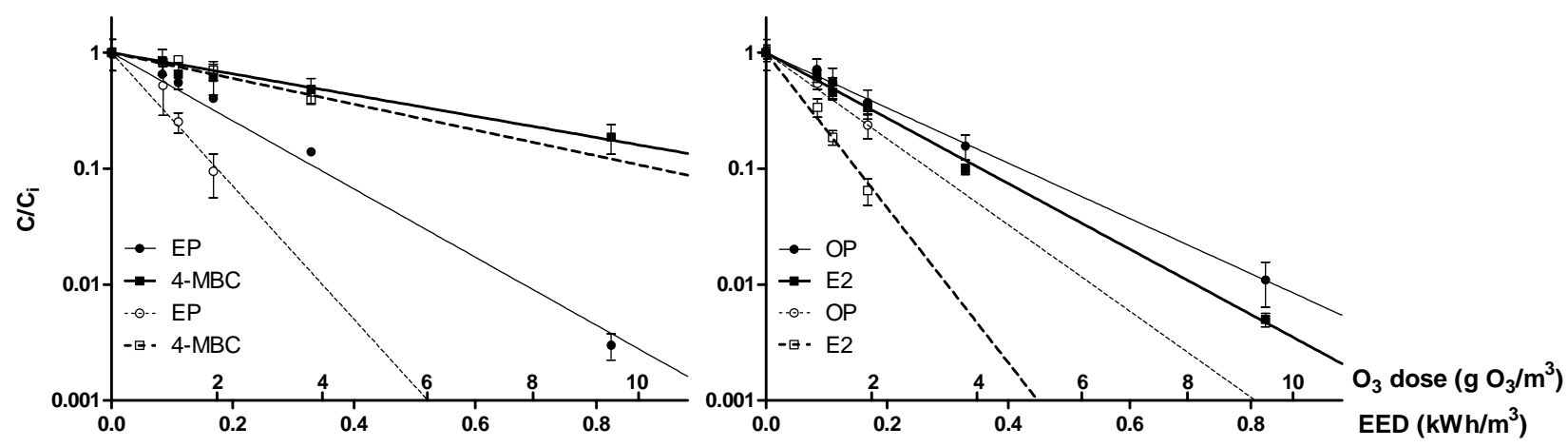

Figure 1. The removal efficiency for ethylparaben (EP), 3-(4-Methylbenzyliden)camphor (4-MBC), octylphenol (OP), and estradiol (E2) in treated sewage from Usserød (open symbols) and Lynetten (closed symbols) WWTPs as function of delivered ozone doze and electrical energy dose for the ozone production.

Analysis of the estrogenic potency of the treated water showed that the potency decreased due to the treatment parallel to the removal of the estrogenic chemicals. The significance of measuring estrogenic potency is that ozone is added in significantly lower concentrations than the COD of the water and therefore chemicals are likely only oxidised to degradation products rather than mineralised. The removal of the estrogenic potency from the water can show that the chemicals have not only been oxidised to change the structure, but the estrogen receptor activation potential is not present in the formed products. Investigation of possible other toxic effects of the degradation products has not been covered in this paper but should not be ignored. 
Table 1. The predicted energy dose, $\mathrm{EEO}\left(\mathrm{kWh} / \mathrm{m}^{3}\right)$ and ozone dose $\mathrm{DDO}_{3}\left(\mathrm{~g} / \mathrm{m}^{3}\right)$ required for 90 $\%$ reduction of the concentration of the investigated compounds in the two effluents with $95 \%$ confidence interval (CI) indicated on the EEO.

\begin{tabular}{|c|c|c|c|c|c|c|c|c|c|}
\hline & & \multicolumn{4}{|c|}{ Usserød WWTP } & \multicolumn{4}{|c|}{ Lynetten WWTP } \\
\hline & & \multicolumn{3}{|c|}{ EEO } & \multirow{2}{*}{$\frac{\mathrm{DDO}_{3}}{2.5}$} & \multicolumn{3}{|c|}{ EEO } & \multirow{2}{*}{$\frac{\mathrm{DDO}_{3}}{7.3}$} \\
\hline & Methylparaben (MP) & 0.20 & \pm & 0.03 & & 0.59 & \pm & 0.06 & \\
\hline & Ethylparaben (EP) & 0.17 & \pm & 0.02 & 2.1 & 0.34 & \pm & 0.01 & 4.2 \\
\hline & Propylparaben (PP) & 0.14 & \pm & 0.01 & 1.7 & 0.38 & \pm & 0.02 & 4.7 \\
\hline & isoButylparaben (isoBP) & 0.18 & \pm & 0.02 & 2.2 & 0.33 & \pm & 0.01 & 4.1 \\
\hline \multirow[t]{2}{*}{ Parabens } & Butylparaben (BP) & 0.20 & \pm & 0.03 & 2.5 & 0.42 & \pm & 0.02 & 5.2 \\
\hline & Bisphenol A (BPA) & 0.25 & \pm & 0.02 & 3.1 & 0.74 & \pm & 0.05 & 9.2 \\
\hline \multirow{2}{*}{$\begin{array}{l}\text { Industrial } \\
\text { phenols }\end{array}$} & isoNonylphenol (isoNP) & 0.18 & \pm & 0.03 & 2.2 & 0.60 & \pm & 0.11 & 7.4 \\
\hline & Octylphenol (OP) & 0.27 & \pm & 0.03 & 3.3 & 0.42 & \pm & 0.02 & 5.2 \\
\hline \multirow{7}{*}{$\begin{array}{l}\text { Sunscreen } \\
\text { chemicals }\end{array}$} & Benzophenone-3 (BP-3) & 0.26 & \pm & 0.02 & 3.2 & 0.28 & \pm & 0.03 & 3.5 \\
\hline & Benzophenone-7 (BP-7) & 0.18 & \pm & 0.01 & 2.2 & 0.36 & \pm & 0.02 & 4.5 \\
\hline & Octyl methoxycinnamate (OMC) & 0.31 & \pm & 0.03 & 3.8 & 0.47 & & 0.08 & 5.8 \\
\hline & Homosalate (HMS) & 0.33 & \pm & 0.05 & 4.1 & \multicolumn{4}{|c|}{ N.D. } \\
\hline & 3-(4-Methylbenzyliden)camphor (4-MBC) & 0.90 & \pm & 0.10 & 11 & 1.09 & \pm & 0.13 & 14 \\
\hline & Octyl Dimethylaminobenzoate (OD-PABA) & 0.15 & \pm & 0.02 & 1.9 & 0.22 & \pm & 0.02 & 2.7 \\
\hline & Estrone (E1) & & & N.D. & & 0.49 & \pm & 0.02 & 6.1 \\
\hline \multirow{2}{*}{$\begin{array}{l}\text { Steroid } \\
\text { estrogens }\end{array}$} & 17- $\beta$-Estradiol (E2) & 0.15 & \pm & 0.01 & 1.9 & 0.35 & \pm & 0.01 & 4.3 \\
\hline & Ethynyl estradiol (EE2) & 0.20 & \pm & 0.02 & 2.5 & 0.50 & \pm & 0.02 & 6.2 \\
\hline $\begin{array}{l}\text { Estrogenic } \\
\text { potency }\end{array}$ & $\begin{array}{l}\text { Estradiol Equivalent concentration (EEC) } \\
\text { according to YES assay }\end{array}$ & 0.23 & \pm & 0.14 & 2.9 & 0.58 & \pm & 0.19 & 7.2 \\
\hline
\end{tabular}

N.D. - no data

\section{Electrical energy per order (EEO)}

The normalised concentration $\left(\mathrm{C} / \mathrm{C}_{\mathrm{i}}\right)$ of the investigated compounds was plotted against the electrical energy dose (EED) used in the treatment (Figure 1 and Table 1). The values of the EEOs for the treatment of the water from Usserød STP were in the range $0.14-0.33 \mathrm{kWh} / \mathrm{m}^{3}$. With the exception of 3-(4-Methylbenzyliden)camphor (4-MBC), which has an EEO of $0.90 \mathrm{kWh} / \mathrm{m}^{3}$. The corresponding results from the experiment with water from Lynetten WWTP showed that more ozone was needed. The EEOs are consequently higher $\left(0.22-0.74 \mathrm{kWh} / \mathrm{m}^{3}\right)$. 4-MBC was once again an exception with a value of $1.09 \mathrm{kWh} / \mathrm{m}^{3}$. The lower reactivity of 4-MBC with ozone is likely explained by ozone reacting very quickly with phenolic functional groups, which most of the estrogenic compounds contain in contrast to 4-MBC. Consequently, the cost for removal of estrogens will be higher in an effluent from Lynetten WWTP compared with effluent from Usserød WWTP. This is presumably because the effluent from Lynetten WWTP contains more oxidizable compounds (COD $59 \mathrm{mg} / \mathrm{L}$ ) than the effluent from Usserød WWTP (COD $44 \mathrm{mg} / \mathrm{L}$ ).

By treating the estrogen equivalent potency as a concentration of a chemical it was possible to calculate EEO for this parameter similar to the individual estrogenic chemicals (table 1). The resulting EEO was similar to the steroid estrogens which is consistent with that most of the estrogenic potency of the mixture of estrogenic chemicals can be explained by these three chemicals. 


\section{Recalculating EEO for full-scale treatment}

The energy cost to produce ozone in the laboratory was determined from ozone output and measured energy consumption at $80.7 \mathrm{kWh} / \mathrm{kg} \mathrm{O}_{3}$. In a real treatment situation a larger and more energy efficient ozone generator will be used. The ozone generator must be fed with oxygen for optimal ozone production and an oxygen generator in situ would be an advantage. The energy consuming from the oxygen generator should be taken into consideration when calculating the energy cost in a real treatment situation. To recalculate energy cost to fit a real treatment situation (50 $000 \mathrm{~m}^{3} /$ day) data on energy consumption and efficiency for oxygen and ozone generators were collected. Data about the ozone generator were taken from a Danish EPA and a water industry report (Danva, 2006). The ozone generator was thus found to use $16 \mathrm{kWh} / \mathrm{kg} \mathrm{O}_{3}$.

To produce the oxygen required for the ozone generator an oxygen generator (OG 300, MVS Engg., 2008 ) with capacity of $300 \mathrm{Nm}^{3} / \mathrm{h}$ (purity 93-95\%) was chosen to estimate the real treatment situation. The oxygen generator uses $0.92 \mathrm{kWh} / \mathrm{m}^{3}$ and thus the energy consumption will be 8.0 $\mathrm{kWh} / \mathrm{kg} \mathrm{O}_{3}$. The total energy required to produce ozone would be $24 \mathrm{kWh} / \mathrm{kg} \mathrm{O}_{3}$. In conclusion, it was found that considering oxygen production and the efficiency of large ozone generators at fullscale treatment, the $\mathrm{EEO}_{\text {real }}$ would be 0.3 times the $\mathrm{EEO}_{\text {experiment }}$

\section{Estimates for real treatment energy consumption}

Use of the EEO allowed estimation of the energy cost at a specific level of removal of any compound, e.g. ethynyl estradiol has an EEO in Usserød WWTP effluent of $0.20 \pm 0.02 \mathrm{kWh} / \mathrm{m}^{3}$, which means that $0.20 \mathrm{kWh} / \mathrm{m}^{3}$ is used to remove $90 \%$ of the compound. The concentration in the effluent of this WWTP has been measured as high as $1.4 \mathrm{ng} / \mathrm{L}$ (Kjølholt et al., 2003) and a likely water quality criterion for the recipient was suggested as $0.35 \mathrm{ng} / \mathrm{L}$ (Caldwell et al., 2008). Thus 75 $\%$ removal efficiency is desired which requires $1.5 \mathrm{~g} \mathrm{O}_{3} / \mathrm{m}^{3}$. In turn this requires an energy dose of $0.12 \mathrm{kWh} / \mathrm{m}^{3}$ with the laboratory reactor or predicted $0.036 \mathrm{kWh} / \mathrm{m}^{3}$ in full scale.

\section{Online control by UV absorbance}

The UV absorbance was higher in the wastewater effluent from Lynetten WWTP $\left(0.230 \mathrm{~cm}^{-1} @\right.$ $254 \mathrm{~nm})$ than in effluent from Usserød WWTP $\left(0.290 \mathrm{~cm}^{-1} @ 254 \mathrm{~nm}\right)$. UV-absorbance spectra taken from both effluents treated with different doses of ozone was used to generate difference spectra between the absorption of the inlet water and the water treated with different doses of ozone as shown in Figure 2.
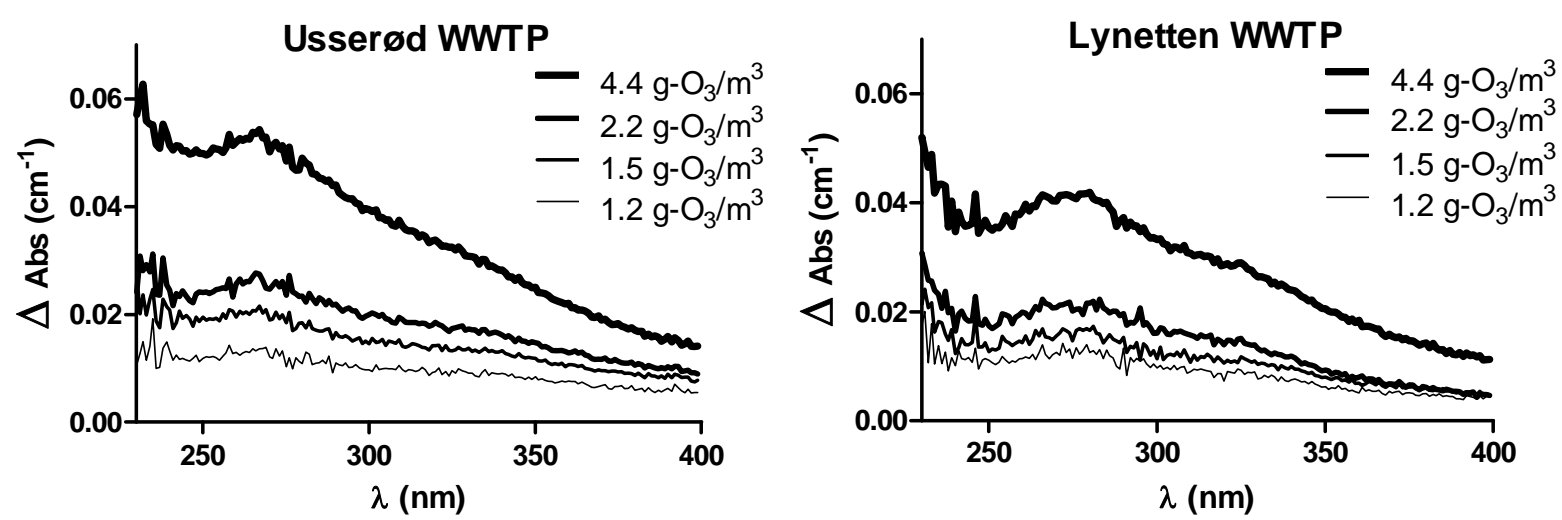

Figure 2. Differential spectra of ozone treated WWTP effluents compared to untreated effluent.

In both WWTP effluents a maximum was observed in the difference in the UV absorbance at about $272 \mathrm{~nm}$. Another maximum was seen at the lowest end of the $\mathrm{nm}$ scale around 220-200 nm. In this part of the spectra the absolute absorbance was high in both treated and untreated effluent and 
therefore the random variation of measured absorbance differences was high. Therefore it seems that measuring the absorbance difference below $220 \mathrm{~nm}$ will not have the same usefulness as a parameter to characterise the ozone treatment. There was an excellent linear correlation between the ozone dose, $\mathrm{DO}_{3}\left(\mathrm{~g} / \mathrm{m}^{3}\right)$, and the difference in absorbance of both wastewaters both at the optimal wavelenght of $272 \mathrm{~nm}$ suggested by the difference spectra and at $254 \mathrm{~nm}$ as previously suggested by Bahr et al., 2007.

$\Delta \mathrm{Abs}_{254 \mathrm{~nm}, \text { Lynetten WWTP }}=0.2890 \pm 0.001-(0.0092 \pm 0.0005) \cdot \mathrm{DO}_{3} ; \mathrm{r}^{2}=0.9894 ; \mathrm{n}=5$

$\Delta \mathrm{Abs}_{272 \mathrm{~nm}, \text { Lynetten } \mathrm{WWTP}}=0.2435 \pm 0.001-(0.0080 \pm 0.0005) \cdot \mathrm{DO}_{3} ; \mathrm{r}^{2}=0.9897 ; \mathrm{n}=5$

$\Delta \mathrm{Abs}_{254 \mathrm{~nm}, \text { Usserød WWTP }}=0.2387 \pm 0.001-(0.0116 \pm 0.0005) \cdot \mathrm{DO}_{3} ; \quad \mathrm{r}^{2}=0.9943 ; \mathrm{n}=5$

$\Delta \mathrm{Abs}_{272 \mathrm{~nm}, \text { Usserød WWTP }}=0.1975 \pm 0.001-(0.0118 \pm 0.0006) \cdot \mathrm{DO}_{3} ; \quad \mathrm{r}^{2}=0.9954 ; \mathrm{n}=5$

The high COD effluent from Lynetten WWTP appeared to be less sensitive to removal of colour by ozonation than the medium COD effluent from Usserød WWTP, but the close $95 \%$ confidence interval on the each of the determined slopes suggests than even differences in ozone doses delivered to the water less than $1 \mathrm{mg} / \mathrm{L}$ could be detected. Therefore a control method of delivered ozone dose to wastewater would rely on determination of a response curve for each source of wastewater. The variation over time of the sensitivity of the colour removal in a WWTP effluents still remains to be determined and this is most important for the usefulness of the method for online control. As both the loss of colour of the water and the removal of the estrogenic chemicals correlate with the ozone dose it is expected that the removal of the investigated compounds will also correlate with the decrease in absorbance at $254 \mathrm{~nm}$ as shown in Table 2 for all chemicals as well as estrogenic potency for both waters. The regression generally fits well except for the chemicals which were removed to below the detection limit of the analytical method with the lowest ozone doses. For most of the estrogens the slope is between 7 and 10. There is no clear different in the values between Usserød WWTP and Lynetten WWTP.

Table 2. Characterisation of the linear correlation $\left(\left(1-\mathrm{C} / \mathrm{C}_{0}\right)=\right.$ slope $\left.\cdot\left(1-\mathrm{Abs}_{254 \mathrm{~nm}} / \mathrm{Abs}_{0,254 \mathrm{~nm}}\right)\right)$ between the removal of estrogens from the effluents and the decolorisation.

\begin{tabular}{ccccc}
\hline & \multicolumn{2}{c}{ Usserød WWTP } & \multicolumn{2}{c}{ Lynetten WWTP } \\
& Slope & $\mathrm{R}^{2}$ & Slope & \multicolumn{1}{c}{$\mathrm{R}^{2}$} \\
\hline MP & 8.8 & 0.86 & 8.1 & 0.93 \\
EP & 9.0 & 0.98 & 8.4 & 0.77 \\
PP & 9.3 & 0.88 & 8.5 & 0.74 \\
isoBP & 9.1 & 0.78 & 8.1 & 0.82 \\
BP & 8.5 & 0.99 & 7.2 & 0.97 \\
BPA & 7.7 & 0.88 & 5.7 & 0.92 \\
isoNP & 7.4 & 0.54 & 7.5 & 0.98 \\
OP & 7.0 & 0.58 & 8.2 & 0.78 \\
BP-3 & 7.4 & 0.77 & 9.2 & 0.72 \\
BP-7 & 9.0 & 0.59 & 9.2 & 0.64 \\
OMC & 5.8 & 0.75 & 8.2 & -0.11 \\
HMS & 4.9 & 0.71 & & N.D. \\
4-MBC & 2.8 & 0.93 & 5.2 & 0.53 \\
OD-PABA & 9.3 & 0.68 & 16.1 & 0.67 \\
E1 & \multicolumn{2}{c}{ N.D. } & 8.2 & 0.46 \\
E2 & 9.9 & 0.06 & 9.0 & 0.57 \\
EE2 & 9.0 & 0.53 & 9.0 & -0.30 \\
EEC & 8.0 & 0.92 & 9.0 & 0.54 \\
\hline
\end{tabular}

N.D. - no data 
The relationship between the decrease in the absorption at $254 \mathrm{~nm}$ and the removal of specific micropollutants was previously showed by Bahr et al. (2007) for a number of pharmaceuticals and the steroid estrogens. Generally the slopes in their work are lower approximately by a factor of two which presumably reflect that the effluent used in that study contained more ozone reactive material that competed with the investigated chemicals for the ozone. This is consistent with that higher ozone doses were needed for both decolourisations and removal of the investigated compounds compared to this study.

The significance of the correlation between reduced UV-absorbance and removal of the estrogenic chemicals investigated is that a control system can be made based on measuring the UV absorbance at $254 \mathrm{~nm}$ before and after the ozone reaction chamber. The output of the ozone generator can then be varied by feedback to attempt to maintain a fixed difference in the measured absorbance values. In periods when the effluent contain less reactive matter which consumes ozone, the ozone generator will save energy by producing less ozone, while as the ozone consumption of the water increases the ozone generators output will increase to match the need so that the same removal rate of estrogenic chemicals is maintained.

\section{CONCLUSIONS}

All estrogenic chemicals could be degraded by ozonation of biologically treated wastewater by applying relatively low doses of ozone. The ozone dose and electrical energy consumption required for any desired removal of each of the investigated chemicals in the two WWTP effluents could be calculated based on the determined EEO. The change of UV-absorbance of the wastewater by reaction with ozone appears to be a suitable parameter for online control of the level of ozonation of effluents in order to minimize the energy consumption while ensuring a desired removal level of estrogenic chemicals as the effluent quality varies. However, more work to characterise the longterm usefullness of the parameter is needed before implementation is realistic.

\section{ACKNOWLEDGMENTS}

The Danish Research council project, DanEd, is gratefully acknowledged for economic support. Thanks to Karina Bomholt Henriksen and Susanne Kruse for valuable technical assistance. We thank the staff at Usserød WWTP and Lynetten WWTP for help with sampling. The yeast strains used were kindly provided by Prof. J. P. Sumpter, Brunel University, Uxbridge, UK.

\section{REFERENCES}

Bahr C., Schumacher J., Ernst M., Luck F., Heinzmann B. and Jekel M. (2007). SUVA as control parameter for the effective ozonation of organic pollutants in secondary effluent. Water Science and Technology, 55(12), 267-274.

Bolton J.R., Bircher K.G., Tumas W. and Tolman C.A. (2001). Figures-of-merit for the technical development and application of advanced oxidation technologies for both electric- and solardriven systems. Pure and Applied Chemistry, 73(4), 627-638.

Brian J. V., Harris C. A., Scholze M., Backhaus T., Booy P., Lamoree M., Pojana G., Jonkers N., Runnalls T., Bonfa A., Marcomini A. and Sumpter J. P. (2005). Accurate prediction of the response of freshwater fish to a mixture of estrogenic chemicals. Environmental Health Perspectives, 113(6), 721-728.

Caldwell D.J., Mastrocco F., Hutchinson T.H., Länge R., Heijerick D., Janssen C., Anderson P.D. and Sumpter J.P. (2008). Derivation of an Aquatic Predicted No-Effect Concentration for the 
Synthetic Hormone, 17a-Ethinyl Estradiol. Environmental Science \& Technology, 42(19), 7046-7054.

DANVA (2006). Videregående renseteknologier for kommunalt spildevand (Advanced treatment technology for municipal wastewater), DANVA Forsknings- og Udredningsprojekt nr. 2, 2006. (Report available from http://www.danva.dk/sw220.asp).

Desbrow C., Rutledge E.J., Brighty G.C., Sumpter J.P. and Waldock M. (1998). Identification of estrogenic chemicals in STW effluent: 1. Chemical fractionation and in vitro biological screening. Environmental Science \& Technology, 32(11), 1549-1558.

Huber M.M., Göbel A., Joss A., Herrmann N., Löffler D., McArdell C.S., Reid A., Siegrist H., Ternes T.A. and von Gunten U. (2005). Oxidation of Pharmaceuticals during Ozonation of Municipal Wastewater Effluents: A Pilot Study. Environmental Science \& Technology, 39(11), 4290-4299.

Joss A., Siegrist H. and Ternes T.A. (2008). Are we about to upgrade wastewater treatment for removing organic micropollutants? Water Science and Technology, 57(2), 251-255.

Kjølholt J., Nielsen P. and Stuer-Lauridsen F. (2003). Hormonforstyrrende stoffer og lagemidler $i$ spildevand (Endocrine chemicals and pharmaceuticals in waste water). Environmental project no. 799. (Report available from http://www.mst.dk).

MVS Engg. (2008) MVS Engineering Limited. http://www.mvsengg.com/psa-oxygen.htm (accessed 2008-07-15).

Purdom C. E., Hardiman P. A., Bye V. J., Eno N. C., Tyler C. R. and Sumpter J. P. (1994). Estrogenic effects of effluents from sewage treatment works. Chemistry and Ecology, 8(4), $275-285$.

Ried A., Mielcke J., Kampmann M., Ternes T., Bonerz M., Herrmann N., Andersen H. and Teiser B. (2003). Ozonation and advanced oxidation processes as an option in wastewater treatment for the elimination of Endocrine Disrupters and Pharmaceuticals. CUTEC 2003.

Ried A., Mielcke J. and Wieland A. (2007). Ozonation of municipal waste water effluent: a tool for the removal of pharmaceuticals, ECDs and pathogens. $5^{\text {th }}$ IWA Specialised Conference on Assessment and Control of Micropollutants / Hazardous Substances in Water, Frankfurt, 276282.

Routledge E. J. and Sumpter J. P. (1996). Estrogenic activity of surfactants and some of their degradation products assessed using a recombinant yeast screen. Environmental toxicology and chemistry, 15(3), 241-248

Routledge E. J., Sheahan D., Desbrow C., Brighty G. C., Waldock M. and Sumpter J. P. (1998). Identification of estrogenic chemicals in STW effluent. 2. In vivo responses in trout and roach. Environmental Science \& Technology, 32, 1559-1565.

Segner H., Caroll K., Fenske M., Janssen C., Maack G., Pascoe D., Schafers C., Vandenbergh G., Watts M. and Wenzel A. (2003). Identification of endocrinedisrupting effects in aquatic vertebrates and invertebrates: report from the European IDEA project. Ecotoxicology and Environmental Safety, 54(3), 302-314.

Ternes T.A., Stuber J., Herrmann N., McDowell D., Ried A., Kampmann M. and Teiser B. (2003). Ozonation: a tool for removal of pharmaceuticals, contrast media and musk fragrances from wastewater?. Water Research, 37(8), 1976-1982. 